\title{
Glucose and urea kinetics in cows in early lactation
}

\author{
BY I. BRUCKENTAL,* J. D. OLDHAM AND J. D. SUTTON \\ National Institute for Research in Dairying, Shinfield, Reading, \\ Berks. $R G_{2} 9 A T$
}

(Received I9 July I979 - Accepted I 2 November 1979)

I. Four mature Friesian cows were used. For 2 weeks after calving they were fed $3 \mathrm{~kg}$ hay (147 $\mathrm{g}$ crude protein (nitrogen $\times 6.25 ; \mathrm{CP}) / \mathrm{kg}$ dry matter (DM)) plus $9 \mathrm{~kg}$ concentrates $(\mathrm{I} 77 \mathrm{~g} \mathrm{CP} / \mathrm{kg} \mathrm{DM}$ ) per d and thereafter $4 \mathrm{~kg}$ hay plus $12 \mathrm{~kg}$ concentrates $/ \mathrm{d}$.

2. At approximately the 2nd, 4th and 9th weeks post-partum each cow was given a single intravenous dose of $\left[{ }^{14} \mathrm{C}\right]$ urea $(1 \mathrm{mCi})$ and $\left[6-{ }^{2} \mathrm{H}\right] \mathrm{glucose}(\mathrm{I} \cdot 5 \mathrm{mCi})$. Following this, jugular venous blood samples were withdrawn up to $26 \mathrm{~h}$ post-injection.

3. The log (specific activity) v. time curves were not linear for either metabolite. Glucose irreversible loss rates (IRL) were calculated by a stochastic procedure. The linear part of the urea log (specific activity) $v$. time curve gave the same estimate for urea IRL rate as a stochastic method of calculation, but urea pool sizes were overestimated so that stochastic analysis of results was preferred.

4. Mean milk yields at the time of the three measurements were $27.1,30.8$ and $27.9 \mathrm{~kg}$ milk/d.

5. Urea IRL was significantly lower $(P<0.05)$ in the first 4 weeks of lactation than in the 9th, and blood urea concentration was lower $(P<0.05)$ in the 4 th than in the 2 nd and 9 th week, but there was no close correlation between urea IRL and concentration.

6. Glucose IRL rose $(P<0.05)$ between the and and gth weeks post-partum, perhaps due to the increase in feed intake. The results were generally consistent with the relationship between milk yield and glucose IRL established by Paterson \& Linzell (1974).

7. Urea IRL $(y)$ and milk protein-N $(x)$ production values were used to calculate the efficiency of protein utilization (EPU) as $x \div(x+0.35 y)$. This assumes that 0.35 of urea IRL was due to protein catabolism. EPU was found to be $0.59-0.80$ (mean 0.69 ).

8. The possible contribution of catabolized amino acids to glucose IRL was calculated by assuming that 0.35 of urea IRL was due to protein catabolism and 0.2 of catabolized protein-C passed through the glucose pool. On this basis the contribution of protein-C to glucose-C was $<25 \mathrm{~g} / \mathrm{kg}$ glucose IRL.

Quantitative aspects of protein metabolism in dairy cows have come under close scrutiny with the publication, recently, of revised systems for defining protein requirements for ruminants (Roy et al. 1977). Application of these systems to dairy cows is limited by a general lack of reliable quantitative information on metabolic processes in cows. In particular there are no published values for direct measurements of the net transfer into milk protein of amino acids absorbed from the gut, although this is a critical factor in the new proposals. Oldham (1978) called this factor the efficiency of protein utilization (EPU) and suggested that it might be measured by quantifying the partition of amino acid-N supplied to the tissues between milk-protein $\mathbf{N}$ and amino acid- $\mathbf{N}$ oxidized to form urea. This paper presents the results of studies we have carried out using this technique.

Because of the particularly high glucose demand of the high-yielding cow, and the need to synthesize a large proportion of this glucose via gluconeogenic pathways, considerable attention has focused on the part which amino acids play in gluconeogenesis in the dairy cow. Hunter \& Millson (1964) and Black et al. (1968) have suggested that as much as $30 \%$ of glucose production may be from amino acid carbon. Oldham (1978), however, has suggested a much lower contribution for the specific instance of the high-yielding cow, because amino acids are in such short supply in comparison with demand. These studies were therefore also designed to measure glucose irreversible loss rates and to

- Present address: Agricultural Research Organisation, The Volcani Center, Institute of Animal Sciences, P.O. Box 6, Bet Dagan, 50-200, Israel. 
relate these to rates of protein catabolism measured by urea production. A similar approach has previously been used by Nolan \& Leng (1970) in pregnant sheep, although they did not study glucose kinetics.

A preliminary report of this work has been published (Bruckental et al. 1978).

\section{EXPERIMENT AL}

Animals and feeding. Four mature Friesian cows were used. Each had calved either two or three times. For the first 2 weeks after calving they were given $9 \mathrm{~kg}$ concentrates and $3 \mathrm{~kg}$ hay daily. On the $15^{\text {th }}$ day after calving the daily ration was increased to $12 \mathrm{~kg}$ concentrates plus $4 \mathrm{~kg}$ hay, and kept at this level for the rest of the experiment. The concentrates contained ( $\mathrm{g} / \mathrm{kg}$ ) 880 barley, Ioo decorticated groundnut meal, 20 mineral + vitamin supplement sufficient to supply mineral and vitamin requirements as given by ARC (I965). Average dry matter (DM) content of the concentrates and hay was $887 \mathrm{~g} / \mathrm{kg}$ and $816 \mathrm{~g} / \mathrm{kg}$ respectively. Concentrates and hay contained $177 \mathrm{~g}$ and $147 \mathrm{~g}$ crude protein (nitrogen $\times 6 \cdot 25$ ) /kg DM respectively.

The concentrates were dispensed in equal portions at hourly intervals from an automatic device. Hay was fed in four portions at equal intervals between 06.00 and 17.00 hours.

There were no refusals of food during the experimental period.

Milk production and live weight change. The cows were milked twice each day at 08.00 and I6.00 hours. Milk yield was recorded, by weight, at each milking. Milk composition was measured routinely in a sample of milk bulked in proportion to yield for four consecutive milkings each week. The cows were weighed on Monday and Friday each week and the weights were averaged to give weekly means.

Experimental procedure. Intravenous injections of $\left[6-{ }^{3} \mathrm{H}\right]$ glucose and $\left[{ }^{14} \mathrm{C}\right]$ urea (The Radiochemical Centre, Amersham, Bucks), were made as near as possible to the 2nd and $4^{\text {th }}$ week after calving in each cow and in the 9 th week in each cow except cow 4 . At $2 \mathrm{~d}$ before each experiment the cows were fitted with indwelling catheters (Portex Ltd, Hythe, Kent) in each jugular vein. At the same time a lightweight fiexible nylon tube (Portex Ltd) was stuck with tissue adhesive over the vulva for collection of urine.

A sample of blood $(20 \mathrm{ml})$ was withdrawn from one catheter immediately before injection of isotopes. Saline $\left(9 \mathrm{~g}\right.$ sodium chloride/1) containing $\mathrm{I} \cdot 5 \mathrm{mCi}\left[6-{ }^{3} \mathrm{H}\right] \mathrm{glucose}$ and I $\mathrm{mCi}\left[{ }^{14} \mathrm{C}\right]$ urea in approximately $20 \mathrm{ml}$ was given as a single injection into one jugular venous catheter, followed by an equal amount of unlabelled saline solution. This procedure took approximately $30 \mathrm{~s}$. Samples of blood were then withdrawn with decreasing frequency, starting at every $3 \mathrm{~min}$, for up to $26 \mathrm{~h}$ after injection.

Urine was collected into bottles containing $50 \mathrm{ml} 18 \mathrm{M}$-sulphuric acid. It was collected for $6 \mathrm{~h}$ periods for $24 \mathrm{~h}$ and then for $12 \mathrm{~h}$ periods for up to $4 \mathrm{~d}$ post injection. Samples were stored frozen $\left(-20^{\circ}\right)$.

Samples of milk were taken at each milking starting at the milking immediately before the injection and then for six further milkings. They were stored individually and frozen $\left(-20^{\circ}\right)$ and were additional to the routine bulk milk samples.

Analyses. Blood samples $(15 \mathrm{ml})$ were immediately deproteinized by laking with deionized water $(30 \mathrm{ml})$ and the addition of $0.15 \mathrm{M}$-barium hydroxide $(15 \mathrm{ml})$ and $0.3 \mathrm{M}$-zinc sulphate $(15 \mathrm{ml}$ ) according to Somogyi (1945); they were then centrifuged at $3000 \mathrm{~g}$ for Io min. The supernatant fractions were stored at $4^{\circ}$ and analysed within $7 \mathrm{~d}$.

The concentration of glucose in the supernatant was measured using an automated procedure (Boehringer, Mannheim) based on the glucose oxidase method of Werner et al. (1970). 
Glucose was prepared for radioactive counting by isolating the $\beta$-glucose penta-acetate (GPA) derivative as described by Jones (1965).

The urea content of the supernatant fraction was measured using an automated procedure based on the method of Marsh et al. (1965). For the first five experiments urea was isolated for radioactive counting by precipitation with dioxan using the procedure described by Cocimano \& Leng (1967). The specific activity of urea so prepared was compared with that calculated if it was assumed that all ${ }^{14} \mathrm{C}$ counts in the supernatant were present as urea. The two methods of measuring urea specific activity gave results which were not significantly different, so subsequently urea specific activity was calculated from the urea concentrations and ${ }^{14} \mathrm{C}$ counts in supernatant fraction.

The concentrations of fat, protein and lactose in milk were measured on an infra-red milk analyser (I.R.M.A. Mark II, Grubb Parsons, Newcastle-upon-Tyne).

Radioactive counting. All samples were counted in a Packard 2450 model dual-channel liquid scintillation counter. Deproteinized blood, GPA and dioxan-precipitated urea were counted in $10 \mathrm{ml}$ of 'normal' phosphor (6 $\mathrm{g}$ Butyl PBD, $0 . \mathrm{I} \mathrm{g}$ POPOP/1 toluene). Urine and milk samples were counted in 'triton' phosphor (7.3 g PPO plus 0.7 POPOP in $450 \mathrm{ml}$ xylene plus $400 \mathrm{ml}$ Triton $\times 100$ plus $150 \mathrm{ml}$ 2-methoxy ethanol). Milk samples were first treated with NCS tissue solubilizer $(0.2 \mathrm{ml}$ milk $+\mathrm{I} \cdot 0 \mathrm{ml} \mathrm{NCS})$.

Interpretation of results. Glucose irreversible loss (IRL) from blood was estimated by stochastic procedures using the analysis described by Shipley \& Clark (1972):

$$
\text { glucose IRL }=\frac{\mathrm{I}}{\int_{0}^{\infty} \mathrm{SA}_{\mathrm{gluc}} d t},
$$

where $\mathrm{I}=$ injected dose of $\left[6-{ }^{3} \mathrm{H}\right]$ glucose $(\mu \mathrm{Ci})$ and $\mathrm{SA}_{\mathrm{gluc}}$ is the specific activity of glucose $(\mu \mathrm{Ci} / \mathrm{mg})$ at time $t$ after injection.

The log (specific activity) $v$. time curves for urea were not linear (see Results) and were interpreted as the sum of two exponential functions:

$$
\mathrm{SA}_{\mathrm{gluc}}=A e^{-\alpha t}+B e^{-\beta t}
$$

Least squares estimates of the two constants ( $A$ and $B$ ) and exponents ( $\alpha$ and $\beta$ ) were obtained and used to describe urea kinetics according to a two-compartment system using procedures described by Shipley \& Clarke (1972). Alternatively the linear part of the curve was used to calculate pool size, fractional outflow and distribution space of urea as if it behaved as a first-order system.

Statistical analysis. Means for results obtained at the three time intervals after calving were compared using analysis of variance adjusted, where necessary, for the missing values for cow 4, week 9 (Snedecor \& Cochran, 1967).

\section{RESULTS}

Milk yield, milk composition and live weight change. The daily yields of milk and its content of fat, protein and lactose in the week of each experiment are shown for each cow in Table I. All measurements were made when the cows were yielding more than $24 \mathrm{~kg} \mathrm{milk} / \mathrm{d}$. Live weights in each experimental period are also shown in Table I. The first measurements were made at a time of rapid body-weight loss and the second and third measurement at slow or zero body-weight loss.

Urea kinetics. A typical log (specific activity) v. time curve for urea is shown in Fig. I. In all cases blood urea specific activity fell rapidly and in curvilinear fashion for $\mathrm{I}-2 \mathrm{~h}$ after injection and then fell more slowly, and linearly until the end of the experiment. As urea 
Table I. Body-weight $(\mathrm{kg})$, milk yield $(\mathrm{kg} / \mathrm{d})$ and the content of fat, protein and lactose in milk $(\mathrm{g} / \mathrm{kg}$ milk) of cows at the time measurements of urea and glucose flux rates were made

\begin{tabular}{|c|c|c|c|c|c|}
\hline Cow no. & $\ldots \quad I$ & 2 & 3 & 4 & Mean \\
\hline \multicolumn{6}{|c|}{ Milk yield (kg/d) } \\
\hline $\begin{array}{c}\text { Week no. } \\
2 \\
4-5 \\
8-9\end{array}$ & $\begin{array}{l}28 \cdot 2 \\
28 \cdot 9 \\
26 \cdot 0\end{array}$ & $\begin{array}{l}26.8 \\
33.5 \\
32.8\end{array}$ & $\begin{array}{l}27 \cdot 3 \\
28 \cdot 0 \\
25 \cdot 0\end{array}$ & $\begin{array}{l}26 \cdot 1 \\
32 \cdot 8 \\
\text { nd }\end{array}$ & $\begin{array}{l}27 \cdot 1 \\
30.8 \\
27.9\end{array}$ \\
\hline \multicolumn{6}{|c|}{ Body-weight } \\
\hline $\begin{array}{r}2 \\
4-5 \\
8-9\end{array}$ & $\begin{array}{l}543 \\
520 \\
524\end{array}$ & $\begin{array}{l}503 \\
480 \\
460\end{array}$ & $\begin{array}{l}568 \\
537 \\
546\end{array}$ & $\begin{array}{r}625 \\
597 \\
\text { nd }\end{array}$ & $\begin{array}{l}560 \\
534 \\
510\end{array}$ \\
\hline \multicolumn{6}{|c|}{ Milk fat } \\
\hline $\begin{array}{r}2 \\
4-5 \\
8-9\end{array}$ & $\begin{array}{l}44 \cdot 0 \\
38 \cdot 9 \\
37 \cdot 5\end{array}$ & $\begin{array}{l}4 \mathrm{I} \cdot \mathrm{I} \\
30 \cdot 7 \\
26 \cdot \mathrm{I}\end{array}$ & $\begin{array}{l}36 \cdot 3 \\
38 \cdot 8 \\
38 \cdot 5\end{array}$ & $\begin{array}{l}73 \cdot 6 \\
4 \mathrm{I} \cdot 0 \\
\text { nd }\end{array}$ & $\begin{array}{l}48 \cdot 8 \\
37 \cdot 4 \\
34.0\end{array}$ \\
\hline \multicolumn{6}{|c|}{ Milk protein } \\
\hline $\begin{array}{r}2 \\
4-5 \\
8-9\end{array}$ & $\begin{array}{l}29 \cdot 6 \\
26 \cdot 3 \\
29 \cdot 1\end{array}$ & $\begin{array}{l}30.8 \\
25.5 \\
25.8\end{array}$ & $\begin{array}{r}32.8 \\
.30 \cdot 7 \\
29.8\end{array}$ & $\begin{array}{l}38 \cdot 4 \\
27 \cdot 7 \\
\text { nd }\end{array}$ & $\begin{array}{l}32 \cdot 9 \\
27 \cdot 6 \\
28 \cdot 2\end{array}$ \\
\hline \multicolumn{6}{|c|}{ Milk lactose } \\
\hline $\begin{array}{r}2 \\
4-5 \\
8-9\end{array}$ & $\begin{array}{l}45 \cdot 7 \\
45 \cdot 3 \\
46 \cdot 8\end{array}$ & $\begin{array}{l}47 \cdot 7 \\
48 \cdot r \\
49 \cdot 9\end{array}$ & $\begin{array}{l}47 \cdot 6 \\
47 \cdot 4 \\
46 \cdot 6\end{array}$ & $\begin{array}{l}41 \cdot 7 \\
47 \cdot 7 \\
\text { nd }\end{array}$ & $\begin{array}{l}45 \cdot 7 \\
47 \cdot 1 \\
47 \cdot 8\end{array}$ \\
\hline \multicolumn{6}{|c|}{ nd, not determined. } \\
\hline
\end{tabular}

is not metabolized in the mammalian system and because it diffuses freely into the water of nearly all body tissues (exceptions include brain (Bradbury \& Coxon, 1962) but represent only a small proportion of body water mass) it seems most reasonable to interpret the first part of the log (specific activity) $v$. time curve as indicating slow mixing of injected $\left[{ }^{14} \mathrm{C}\right]$ urea with the body urea pool.

Analysis of the curve as the sum of two exponential functions was used to describe the kinetics of mixing. A possible two-compartment model is shown in Fig. 2 in which urea enters and leaves the primary compartment (that is the compartment into which $\left[{ }^{14} \mathrm{C}\right]$ urea was injected and from which samples were taken so that it must include blood) and exchanges between the primary $(a)$ and secondary $(b)$ compartments. A model of this type is probably appropriate to describe mixing of urea in blood with the rest of the urea distribution space. Fig. 2 suggests that the distribution space of urea in the primary compartment was about three times blood volume, if blood volume was $6 \%$ of live weight and if the concentration of urea was uniform throughout the primary compartment.

Table 2 shows the calculated measurements of urea metabolism. Urea IRL rates were calculated $(a)$ as IRL from the two-compartment exchanging system shown in Fig. 2 (these values are identical to those obtained by dividing the injected dose by the area beneath the specific activity $v$. time curve (integral of the equation fitted to values)) and (b) by relying on the linear part of the log (specific activity) $v$. time curve and assuming first-order kinetics.

Estimates of urea IRL calculated by the two procedures were not significantly different. Values from the two-compartment model have been adopted to compare urea IRL at different times after calving (Table 2).

IRL was significantly lower $(P<0.05)$ in weeks 2 and 4 than in week 9 after calving. 


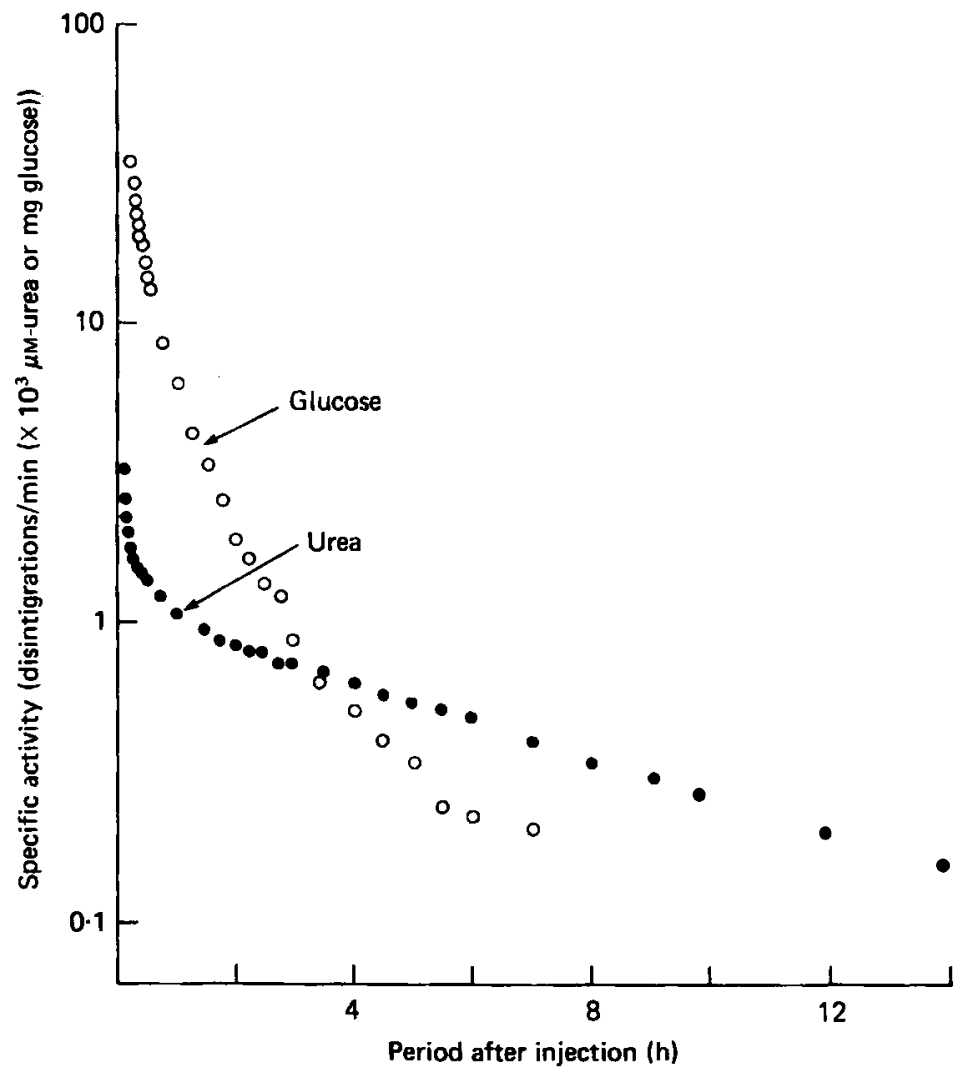

Fig. I. Decline in specific activity of glucose and urea in jugular venous blood with time following single intravenous injection of $\left[6^{-3} \mathrm{H}\right] \mathrm{glucose}(\mathrm{O})$ and $\left.{ }^{14} \mathrm{C}\right] \mathrm{urea}(O)$ in cows in early lactation.

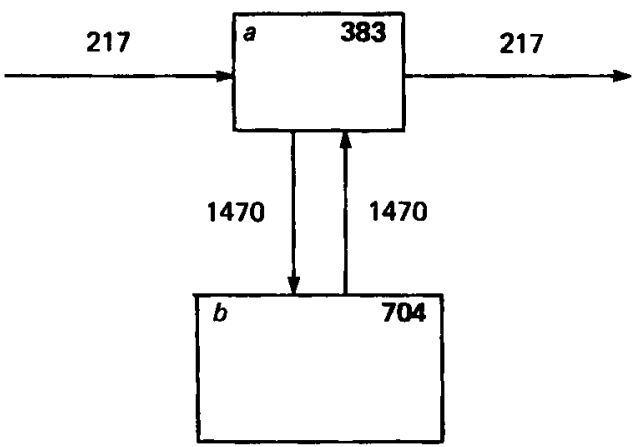

Fig. 2. Kinetics of urea metabolism described as a two-compartment exchanging system in cows in early lactation. Pool $a$ is the pool into which $\left[{ }^{24} \mathrm{C}\right]$ urea was injected and from which samples were taken. It therefore includes blood. Values for pool sizes (mM; 'bold' values) and flux rates $(\mathrm{mm} / \mathrm{h})$ are means for the four cows 4 weeks post-partum. 
Table 2. Measurements of urea metabolism in cows at three stages of lactation

(Values for individual measurements and the means for measurements made in the 2nd, 4 th and 9th weeks after calving. Means are adjusted for a missing value in the gth week)

\begin{tabular}{|c|c|c|c|c|c|c|c|}
\hline \multirow{2}{*}{$\begin{array}{l}\text { Cow } \\
\text { no. }\end{array}$} & \multirow{2}{*}{$\begin{array}{l}\text { Period } \\
\text { post- } \\
\text { partum } \\
\text { (d) }\end{array}$} & \multirow{2}{*}{$\begin{array}{l}\text { Blood urea } \\
\text { concentration } \\
\text { (mM/l) }\end{array}$} & \multirow{2}{*}{$\begin{array}{c}\text { Urea IRL } \\
(\mathrm{mm} / \mathrm{h})\end{array}$} & \multicolumn{2}{|c|}{$\begin{array}{l}\text { Urea pool size } \\
\underset{(\mathrm{M})}{ }\end{array}$} & \multicolumn{2}{|c|}{$\begin{array}{l}\text { Urea distribution } \\
\text { (l/kg body-wt) }\end{array}$} \\
\hline & & & & $I^{*}$ & $2 \dagger$ & $I^{*}$ & $2 \dagger$ \\
\hline I & $\begin{array}{l}13 \\
37 \\
65\end{array}$ & $\begin{array}{l}4 \cdot 36 \\
4 \cdot 24 \\
4 \cdot 50\end{array}$ & $\begin{array}{l}219 \\
269 \\
294\end{array}$ & $\begin{array}{l}I \cdot 49 \\
1 \cdot 39 \\
1 \cdot 30\end{array}$ & $\begin{array}{l}1 \cdot 77 \\
1.85 \\
1 \cdot 94\end{array}$ & $\begin{array}{l}0.63 \\
0.63 \\
0.55\end{array}$ & $\begin{array}{l}0.75 \\
0.84 \\
0.82\end{array}$ \\
\hline 2 & $\begin{array}{l}15 \\
28 \\
55\end{array}$ & $\begin{array}{l}3.88 \\
3.39 \\
4.21\end{array}$ & $\begin{array}{l}199 \\
238 \\
399\end{array}$ & $\begin{array}{l}1 \cdot 18 \\
0.98 \\
I \cdot 21\end{array}$ & $\begin{array}{l}1 \cdot 63 \\
1 \cdot 28 \\
1 \cdot 74\end{array}$ & $\begin{array}{l}0.60 \\
0.60 \\
0.62\end{array}$ & $\begin{array}{l}0.84 \\
0.79 \\
0.90\end{array}$ \\
\hline 3 & $\begin{array}{l}12 \\
33 \\
67\end{array}$ & $\begin{array}{l}4 \cdot 27 \\
3 \cdot 40 \\
4 \cdot 59\end{array}$ & $\begin{array}{l}231 \\
142 \\
286\end{array}$ & $\begin{array}{l}1.80 \\
1.05 \\
1.43\end{array}$ & $\begin{array}{l}2 \cdot 20 \\
1 \cdot 18 \\
1 \cdot 97\end{array}$ & $\begin{array}{l}0.74 \\
0.58 \\
0.57\end{array}$ & $\begin{array}{l}0.91 \\
0.65 \\
0.79\end{array}$ \\
\hline 4 & $\begin{array}{l}13 \\
33\end{array}$ & $\begin{array}{l}4 \cdot 13 \\
3.07\end{array}$ & $\begin{array}{l}273 \\
219\end{array}$ & $\begin{array}{l}I \cdot 71 \\
0.93\end{array}$ & $\begin{array}{l}1 \cdot 90 \\
1 \cdot 25\end{array}$ & $\begin{array}{l}0.66 \\
0.51\end{array}$ & $\begin{array}{l}0.74 \\
0.68\end{array}$ \\
\hline Week & $\begin{array}{l}0 .: 2 \\
4-5 \\
8-9\end{array}$ & $\begin{array}{l}4 \cdot 16^{\mathrm{a}} \\
3 \cdot 53^{\mathrm{b}} \\
4 \cdot 35^{\mathrm{a}}\end{array}$ & $\begin{array}{l}231^{\mathrm{ab}} \\
217^{\mathrm{b}} \\
334^{\mathrm{a}}\end{array}$ & $\begin{array}{l}1 \cdot 55^{\mathrm{a}} \\
1 \cdot 09^{\mathrm{b}} \\
1 \cdot 32^{\mathrm{ab}}\end{array}$ & $\begin{array}{l}1.88 \\
1 \cdot 39 \\
1 \cdot 87\end{array}$ & $\begin{array}{l}0.66 \\
0.58 \\
0.61\end{array}$ & $\begin{array}{l}0.81 \\
0.74 \\
0.82\end{array}$ \\
\hline $\begin{array}{l}\text { SE C } \\
\text { be }\end{array}$ & $\begin{array}{l}\text { difference } \\
\text { een mean }\end{array}$ & 0.214 & $40 \cdot I$ & $0 \cdot 164$ & 0.205 & 0.059 & 0.064 \\
\hline
\end{tabular}

IRL, irreversible loss rate.

a, b, means in same column with unlike superscripts differed significantly $(P<0.05)$.

* Calculated from two-pool model, see p. 39.

$\dagger$ Calculated assuming first-order kinetics, see p. 39.

Table 3. Measurements of glucose metabolism in cows at three stages of lactation

(Values for individual measurements and the means for measurements made in the 2nd, 4th and gth weeks post-partum. Means are adjusted for a missing value in the gth week)

\begin{tabular}{|c|c|c|c|c|c|}
\hline Cow no. & $\begin{array}{c}\text { Period } \\
\text { post-partum } \\
\text { (d) }\end{array}$ & $\begin{array}{l}\text { Glucose } \\
(\mathrm{mM} / \mathrm{l})\end{array}$ & $\begin{array}{c}\text { Glucose IRL } \\
(\mathrm{g} / \mathrm{h})\end{array}$ & $\begin{array}{c}\text { Milk-lactose-C } \\
\text { output } \\
(\mathrm{g} / \mathrm{d})\end{array}$ & $\begin{array}{c}\text { Milk-lactose-C } \\
\text { as proportion } \\
\text { of } \\
\text { glucose-C IRL }\end{array}$ \\
\hline I & $\begin{array}{l}13 \\
37 \\
65\end{array}$ & $\begin{array}{l}2 \cdot 42 \\
2 \cdot 66 \\
2 \cdot 27\end{array}$ & $\begin{array}{r}91 \\
123 \\
121\end{array}$ & $\begin{array}{l}542 \\
559 \\
511\end{array}$ & $\begin{array}{l}0.62 \\
0.47 \\
c .44\end{array}$ \\
\hline 2 & $\begin{array}{l}15 \\
28 \\
55\end{array}$ & $\begin{array}{l}1 \cdot 77 \\
2 \cdot 66 \\
2 \cdot 81\end{array}$ & $\begin{array}{r}94 \\
133 \\
144\end{array}$ & $\begin{array}{l}537 \\
677 \\
689\end{array}$ & $\begin{array}{l}0.60 \\
0.53 \\
0.50\end{array}$ \\
\hline 3 & $\begin{array}{l}12 \\
33 \\
67\end{array}$ & $\begin{array}{l}2 \cdot 50 \\
2 \cdot 57 \\
2 \cdot 61\end{array}$ & $\begin{array}{l}113 \\
106 \\
124\end{array}$ & $\begin{array}{l}493 \\
558 \\
490\end{array}$ & $\begin{array}{l}0.45 \\
0.55 \\
0.41\end{array}$ \\
\hline 4 & $\begin{array}{l}13 \\
33\end{array}$ & $\begin{array}{l}2 \cdot 60 \\
2 \cdot 41\end{array}$ & $\begin{array}{r}82 \\
119\end{array}$ & $\begin{array}{l}48 \mathrm{r} \\
659\end{array}$ & $\begin{array}{l}0.61 \\
0.58\end{array}$ \\
\hline & $\begin{array}{r}\text { k no.: } 2 \\
4-5 \\
8-9\end{array}$ & $\begin{array}{l}2 \cdot 32 \\
2 \cdot 58 \\
2 \cdot 58\end{array}$ & $\begin{array}{l}95^{\mathrm{b}} \\
120^{\mathrm{ab}} \\
127^{\mathrm{a}}\end{array}$ & $\begin{array}{l}513^{\mathrm{b}} \\
613^{\mathrm{a}} \\
566^{\mathrm{ab}}\end{array}$ & $\begin{array}{l}0.57 \\
0.53 \\
0.46\end{array}$ \\
\hline $\begin{array}{l}\text { SE of } \\
\text { betw }\end{array}$ & $\begin{array}{l}\text { ifference } \\
\text { en means }\end{array}$ & 0.267 & IO $\cdot I$ & $38 \cdot 5$ & 0.045 \\
\hline
\end{tabular}

IRL, irreversible loss rate.

a, b, means in the same column which do not share a common superscript differ significantly $(P<0.05)$. 
This contrasts with the observed difference in blood urea concentration, which fell between weeks 2 and $4(P<0.05)$ and then rose again by week $9(P<0.05$; Table 2$)$. Plasma urea concentration and urea IRL were not closely related.

Urea pool sizes were also estimated by two procedures: $(a)$ as the sum of the compartments shown in Fig. 2 or (b) by using the zero-time intercept obtained by extrapolating the linear part of the $\log$ (specific activity) $v$. time curve. Table 3 shows that pool size estimates were consistently, and significantly $(P<0.05)$ higher when calculated by extrapolation.

With the assumption that urea concentration throughout its distribution volume is constant, distribution volume was calculated according to each of the pool size estimates shown in Table 3. The extrapolation procedure suggests urea distribution space was $0.69-$ $0.9 \mathrm{I} 1 / \mathrm{kg}$ body-weight, the two-pool model that it was $0.5 \mathrm{I}-0.74 \mathrm{l} / \mathrm{kg}$ body-weight.

As distribution space has been found to be at least $95 \%$ of body water volume (McCance \& Widdowson, 195I; Bradbury, 196I) it is reasonable to expect the urea distribution space measured in these experiments to be close to body water volume, which has been found to be $0.6 \mathrm{I}-0.651 / \mathrm{kg}$ body-weight in Friesian cows (Ellenberger et al. 1950; Kamal \& Sief, 1969). Using this as a basis for assessment the value based on the two-compartment model is probably a better estimate of urea distribution space.

The mean recoveries of injected ${ }^{14} \mathrm{C}$ in milk and in urine were found to be 13 and $22 \%$ respectively. Some loss of urine from the collection tubes was observed occasionally, so that the measured recovery of ${ }^{14} \mathrm{C}$ was not absolutely quantitative and the results should be considered with this in mind.

Glucose kinetics. A typical log (specific activity) v. time curve for glucose is shown in Fig. I. Comparisons of glucose IRL between times after calving show (Table 3) that glucose IRL was significantly $(P<0.05)$ lower in week 2 than in subsequent measurements. Because food intake was increased after the first measurement this change in glucose IRL could have been due to either the change in food intake or stage of lactation or both.

Other work has shown that at least $85 \%$ of lactose is synthesized from glucose in lactating cows (Bickerstaffe et al. 1974) so it was of interest to compare rates of milk lactose output with glucose IRL. Table 3 shows that, on a C basis, milk lactose output accounted for a decreasing proportion of glucose IRL as lactation progressed. The mean values fell from $0.57 P^{4}$ week 2 to 0.46 at week 9 .

\section{DISCUSSION}

\section{Glucose metabolism}

$\left[6-{ }^{3} \mathrm{H}\right]$ glucose was used to measure the kinetics of glucose metabolism because of the high expense of [ $\left.\mathrm{U}-{ }^{14} \mathrm{C}\right] \mathrm{glucose}$ for experiments of this type with high-yielding dairy cows. It was chosen in preference to other forms of tritiated glucose because, where comparisons have been made in ruminants, glucose labelled at $\mathrm{C} 6$ has been found to give estimates of glucose IRL most similar to those measured with [U-14C]glucose (Judson \& Leng, I972; Brockman et al. 1975; Kronfeld, 1977). The aim was to measure net glucose utilization at three stages of lactation and in relation to protein metabolism. It is recognized that glucose IRL measured by isotope dilution is not an absolute measure of glucose utilization rate (Shipley \& Clark, 1972; Katz et al. 1974), the error being the extent to which label recycles to glucose on a time scale greater than that of an individual measurement. With current methodology this error is inevitable, but must be borne in mind in interpreting results.

The magnitude of these glucose IRL estimates was similar to those reported by Horsfield et al. (1974) for Friesian cows of similar milk yield. Paterson \& Linzell (1974) described 
a relationship between glucose entry rate $\left(y ; \mathrm{mg} / \mathrm{min}\right.$ per $\mathrm{kg}$ body-weight $\left.{ }^{0.75}\right)$ and milk yield $(x ; 1 / d)$ such that:

$$
y=0.374( \pm 0.047) x+5.36( \pm 0.72)
$$

They used both their own and other published values to establish this relationship (in all instances except for the values of Kronfeld et al. (1968) measured glucose 'entry rate' was equivalent to 'irreversible loss' in the present study). In only four of thirty-seven pairs of results did milk yield exceed $22 \mathrm{l} / \mathrm{d}$. Our values for glucose IRL for milk yields of $25-33.5 \mathrm{~kg} / \mathrm{d}$ were equivalent to $\mathrm{I} \cdot 8 \mathrm{I}-4.02 \mathrm{mg} / \mathrm{min}$ per $\mathrm{kg}$ body-weight $\mathrm{t}^{0.75}$ and were generally consistent with their relationship between milk yield and glucose 'entry rate'. Our results therefore reinforce the suggestion that non-mammary utilization of glucose does not change during lactation at least for milk yields to $30 \mathrm{~kg} / \mathrm{d}$. This does not mean that milk yield is the only determinant of glucose IRL; other factors such as level of food intake (Judson \& Leng, 1968) and roughage:concentrate value in food (Bickerstaffe et al. 1974; Evans et al. 1975) are likely to be important. In the present experiment glucose IRL rose when food intake increased, but this observation was confounded by coincident changes in stage of lactation and milk yield.

The fate of glucose 'irreversibly lost' clearly changed with stage of lactation in these cows. Although glucose is not an essential precursor of all lactose-C (Lindsay, 1979) it has been found, in practice, to supply approximately $90 \%$ of lactose-C (Annison et al. 1974; Bickerstaffe et al. 1974) and it is reasonable to expect that this was so here. A fall between 2 and 9 weeks post-partum in the milk lactose-C production:glucose-C IRL value from 0.57 to 0.46 suggests that an increase in oxidation of glucose is to be expected over this period. This is consistent with the findings of Bennink et al. (1972). The changes in glucose dissimilation as lactation progresses are similar in nature to those found in sheep (Bergman \& Hogue, 1967).

\section{Urea metabolism}

Mugerwa \& Conrad (197I) and Conrad (1972) have previously reported studies on urea metabolism in lactating cows, but the present work is the first to report changes in urea production with stage of lactation in cows yielding more than $20 \mathrm{~kg} \mathrm{milk} / \mathrm{d}$. The magnitude of urea IRL measured here $(0.26-0.87 \mathrm{~mm} / \mathrm{h}$ per $\mathrm{kg}$ body-weight) was however similar to those found in Jersey cows given diets containing up to $62 \mathrm{~g}$ urea $/ \mathrm{kg} \mathrm{DM}(0.4 \mathrm{I}-0.89 \mathrm{mM} / \mathrm{h}$ per kg body-weight; Mugerwa \& Conrad, I97I). It was also similar to values found in sheep (0.10-I.23 mM/h per kg body-weight; Cocimano \& Leng, I967; 0.26-0.89; Ford \& Milligan, 1970) and goats (0.5-0.8; Engelhardt et al. 1978).

There appeared to be changes in urea IRL with stage of lactation. As urea IRL remained low for 2 weeks after the change in level of feeding and then rose, it seems likely that this was more a response to the demands of lactation at that time than to the change in ration. It would therefore appear that nitrogen was being conserved for milk- $\mathbf{N}$ formation at this time.

Other work has shown that plasma urea concentration often falls post-partum in cows (Treacher et al. 1976). The present work suggests that the fall in concentration reflects a fall in urea IRL, or production, although the correlation between concentration and production found here was not particularly close, possibly because urea concentration varied over only a relatively small range in these experiments.

The measured total recovery of injected ${ }^{14} \mathrm{C}$ in urine and milk from these cows was $18-60 \%$ (mean 36\%) which is less than has been found in mature non-pregnant, nonlactating ruminants given adequate diets (Cocimano \& Leng, 1967; Nolan \& Leng, I970; Allen \& Miller, 1976) but similar to values from pregnant (Nolan \& Leng, 1970), growing 


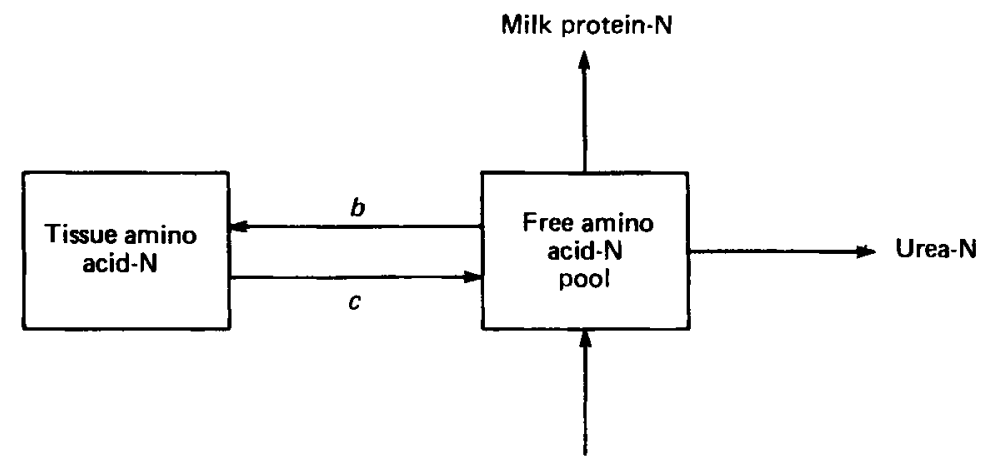

Absorbed amino acid- $\mathbf{N}$

Fig. 3. A simple model to describe the sources and fate of amino acid-nitrogen entering the body free amino acid-N pool. For details, see p. 4 I.

(Allen \& Miller, 1976) or lactating (Mugerwa \& Conrad, 1971) ruminants. Label not recovered in urine or milk has conventionally been taken as a measure of urea degradation in the gastrointestinal tract. With the proviso that our results may be underestimates due to incomplete collection of urine, they do in general accord with the hypothesis that urea degradation is proportionately greater in productive ruminants. The present work lends support to the general hypothesis that this could act as an $\mathrm{N}$-conserving mechanism in animals with a high protein demand such as high-yielding cows, but does not reveal anything of the precise mechanisms, which are known to be complex (Engelhardt et al. I978).

\section{Efficiency of protein utilization (EPU)}

The simple model of protein-N metabolism shown in Fig. 3 was used to calculate the efficiency of use of protein- $\mathrm{N}$ for milk production in the present experiment.

The assumptions in the model require comment. First the model assumes that amino- $N$ is either used productively, i.e. for tissue or milk $\mathbf{N}$ formation, or that it passes through the urea pool from which urea is excreted. This is not true for all protein-N as some proteins (some plasma proteins, digestive enzymes and gut epithelial cell proteins) are excreted with faeces. The magnitude of these losses of protein- $\mathrm{N}$ which have at no time passed through the urea pool cannot be accurately defined. Recently Ørskov \& Grubb (1979) have suggested that truly endogenous faecal loss of $N$ is similar in quantity to endogenous urinary $\mathrm{N}$ loss, which may be $\log \mathrm{N} / \mathrm{d}$ for dairy cows of the weight used here (Roy et al. 1977). This is small compared with our estimates of urea- $\mathrm{N}$ formation $(95-267 \mathrm{~g} / \mathrm{d})$ and suggests that our assumption is reasonable.

A second and greater problem is that not all urea is formed as a result of catabolism of the free amino acid-N pool (Fig. 3). Substantial amounts of urea-N are derived from ammonia absorbed from the gut (Nolan, 1975) and some, though smaller, quantities come from the catabolism of other metabolites, notably pyrimidines (Mahler \& Cordes, 197I).

Nolan (1975) has described the quantitative contributions of gut ammonia-N and ' $N$ bases' to urea-N production in mature sheep given lucerne hay. These together accounted for 0.71 of urea-N production. The remainder would largely be the contribution of amino- $\mathrm{N}$ to urea- $\mathrm{N}$, which therefore was 0.29 of urea- $\mathrm{N}$ formation in those circumstances.

Nolan's (1975) are the only published values relevant to our present approach. Extrapolation from the mature wether sheep to the high-yielding dairy cow is clearly dangerous, 
Table 4. Calculation of minimum and 'corrected' efficiency of protein utilization (EPU) from milk protein yield and urea irreversible loss rate (IRL)

\begin{tabular}{|c|c|c|c|c|c|c|}
\hline $\begin{array}{l}\text { Cow } \\
\text { no. }\end{array}$ & $\begin{array}{c}\text { Measurement } \\
\text { no. }\end{array}$ & $\begin{array}{l}\text { Milk protein } \\
\text { yield } \\
\text { (g/d) }\end{array}$ & $\begin{array}{c}\text { Urea CP* } \\
\text { equivalent } \\
(\mathrm{g} / \mathrm{d})\end{array}$ & $\begin{array}{c}\text { Minimum } \\
\text { EPU }\end{array}$ & $\begin{array}{c}\text { Protein or } \\
\text { amino } \\
\text { acid-nitrogen } \\
\text { catabolized to } \\
\text { form urea }(\mathrm{g} / \mathrm{d}) \dagger\end{array}$ & $\begin{array}{c}\text { Corrected } \\
\text { EPU† }\end{array}$ \\
\hline I & $\begin{array}{l}1 \\
2 \\
3\end{array}$ & $\begin{array}{l}793 \\
722 \\
719\end{array}$ & $\begin{array}{r}920 \\
1130 \\
1235\end{array}$ & $\begin{array}{l}0.46 \\
0.39 \\
0.37\end{array}$ & $\begin{array}{l}322 \\
396 \\
432\end{array}$ & $\begin{array}{l}0.71 \\
0.65 \\
0.62\end{array}$ \\
\hline 2 & $\begin{array}{l}\mathbf{1} \\
2 \\
3\end{array}$ & $\begin{array}{l}784 \\
812 \\
804\end{array}$ & $\begin{array}{r}836 \\
1000 \\
1676\end{array}$ & $\begin{array}{l}0.45 \\
0.45 \\
0.32\end{array}$ & $\begin{array}{l}293 \\
350 \\
587\end{array}$ & $\begin{array}{l}0.73 \\
0.70 \\
0.59\end{array}$ \\
\hline 3 & $\begin{array}{l}1 \\
2 \\
3\end{array}$ & $\begin{array}{l}851 \\
817 \\
708\end{array}$ & $\begin{array}{r}970 \\
596 \\
1201\end{array}$ & $\begin{array}{l}0.47 \\
0.58 \\
0.37\end{array}$ & $\begin{array}{l}340 \\
209 \\
420\end{array}$ & $\begin{array}{l}0.71 \\
0.80 \\
0.63\end{array}$ \\
\hline 4 & $\begin{array}{l}\mathbf{I} \\
\mathbf{2}\end{array}$ & $\begin{array}{l}952 \\
863\end{array}$ & $\begin{array}{r}1147 \\
920\end{array}$ & $\begin{array}{l}0.45 \\
0.48\end{array}$ & $\begin{array}{l}401 \\
322\end{array}$ & $\begin{array}{l}0.70 \\
0.73\end{array}$ \\
\hline \multicolumn{7}{|c|}{$\begin{array}{l}\text { Mean week } \\
\text { no. }\end{array}$} \\
\hline & $\begin{array}{r}2 \\
4-5 \\
8-9\end{array}$ & - & - & $\begin{array}{l}0.46 \\
0.48 \\
0.35\end{array}$ & E & $\begin{array}{l}0.71 \\
0.72 \\
0.61\end{array}$ \\
\hline
\end{tabular}

CP, crude protein.

* Urea- $N(\mathrm{~g} / \mathrm{d}) \times 6.25$. This is an estimate of the amount of protein catabolized to yield the amount of urea measured as urea IRL $(\mathrm{g} / \mathrm{d})$.

$\dagger$ Assumes that 0.35 of urea- $\mathrm{N}$ irreversible loss is equivalent to urea- $\mathrm{N}$ formation from amino acid catabolism.

but it is relevant to note that the concentration of $\mathrm{N}$ was similar in the diet fed by Nolan (1975) and in the one used here. Also, the transfer of rumen $\mathrm{NH}_{3}{ }^{-15} \mathrm{~N}$ in two of the cows used in the present studies showed that 0.1 and 0.28 of urea- $\mathrm{N}$ production was from $\mathrm{N}$ which had passed through the rumen $\mathrm{NH}_{3}-\mathrm{N}$ pool (Oldham et al. I980). In Nolan's (1975) model, 0.32 of urea- $\mathrm{N}$ was formed from the rumen $\mathrm{NH}_{3}-\mathrm{N}$ which was absorbed. There is a difference between the two estimates in that our measurement does not discriminate between urea- $\mathrm{N}$ formed directly from rumen $\mathrm{NH}_{3}-\mathrm{N}$ absorbed and that which has come from catabolized microbial $\mathrm{N}$ formed initially from rumen $\mathrm{NH}_{3}-\mathrm{N}$. In general though, the similarity of the two estimates suggests that in the light of available information it is reasonable to use Nolan's (1975) model for sheep to help interpret our results for cows.

From Nolan's (1975) model, 0.29 of urea-N production may be attributed to protein-N catabolism. Allowing a margin for error we have assumed here that 0.35 of urea- $\mathrm{N}$ production was due to protein-N catabolism. The effect of this adjustment is to reduce estimates of EPU slightly.

Because our cows were either losing or maintaining body-weight during the experiment it seems reasonable to assume that body protein mass did not increase over this time period, so that, in Fig. $3 b \leqslant c$. EPU can then be defined as:

$$
\frac{x}{x+0.35 y}
$$

where $x$ is the milk protein-N output, and $y$ is the urea-N IRL (equivalent to net production).

This is subsequently referred to as 'corrected EPU'. 
Table 5. Calculation of the possible contribution of protein

to glucose irreversible loss rate (IRL)

\begin{tabular}{|c|c|c|c|c|c|c|}
\hline \multirow[b]{2}{*}{$\begin{array}{l}\text { Cow } \\
\text { no. }\end{array}$} & \multirow{2}{*}{$\begin{array}{c}\text { Measurement } \\
\text { no. }\end{array}$} & \multirow{2}{*}{$\begin{array}{l}\text { Glucose IRL } \\
(\mathrm{g} / \mathrm{d})\end{array}$} & \multirow{2}{*}{$\begin{array}{l}\text { Urea CP* } \\
\text { equivalent } \\
\text { (g/d) }\end{array}$} & \multicolumn{3}{|c|}{$\begin{array}{l}\text { The proportion of glucose IRL } \\
\text { derived from protein } \dagger\end{array}$} \\
\hline & & & & If & $2 \S$ & $3 \|$ \\
\hline I & $\begin{array}{l}\mathbf{I} \\
2 \\
3\end{array}$ & $\begin{array}{l}2184 \\
2952 \\
2904\end{array}$ & $\begin{array}{r}920 \\
1130 \\
1235\end{array}$ & $\begin{array}{l}0.23 \\
0.21 \\
0.23\end{array}$ & $\begin{array}{l}0.081 \\
0.074 \\
0.082\end{array}$ & $\begin{array}{l}0.016 \\
0.015 \\
0.016\end{array}$ \\
\hline 2 & $\begin{array}{l}\mathbf{I} \\
\mathbf{2} \\
\mathbf{3}\end{array}$ & $\begin{array}{l}2256 \\
3192 \\
3456\end{array}$ & $\begin{array}{r}836 \\
1000 \\
1676\end{array}$ & $\begin{array}{l}0.20 \\
0.17 \\
0.27\end{array}$ & $\begin{array}{l}0.071 \\
0.060 \\
0.093\end{array}$ & $\begin{array}{l}0.014 \\
0.012 \\
0.019\end{array}$ \\
\hline 3 & $\begin{array}{l}\text { I } \\
2 \\
3\end{array}$ & $\begin{array}{l}2712 \\
2544 \\
2976\end{array}$ & $\begin{array}{r}970 \\
596 \\
\text { I } 201\end{array}$ & $\begin{array}{l}0.20 \\
0.13 \\
0.22\end{array}$ & $\begin{array}{l}0.069 \\
0.045 \\
0.078\end{array}$ & $\begin{array}{l}0.014 \\
0.009 \\
0.016\end{array}$ \\
\hline 4 & $\begin{array}{l}\mathbf{I} \\
\mathbf{2}\end{array}$ & $\begin{array}{l}1968 \\
2856\end{array}$ & $\begin{array}{r}1147 \\
920\end{array}$ & $\begin{array}{l}0.32 \\
0.18\end{array}$ & $\begin{array}{l}0.112 \\
0.062\end{array}$ & $\begin{array}{l}0.022 \\
0.012\end{array}$ \\
\hline
\end{tabular}

CP, crude protein.

- Urea CP equivalent $=$ urea-N IRL $\times 6.25 \mathrm{~g} / \mathrm{d}$.

$\dagger$ All calculations assume that $550 \mathrm{~g}$ glucose can be synthesized from $1 \mathrm{~kg}$ protein and the potential for glucose synthesis from protein $(\mathrm{g} / \mathrm{d})$ is given as a proportion of measured glucose IRL.

$\ddagger$ Assumes that all urea- $\mathrm{N}$ is produced from catabolized protein and that all catabolized protein $\mathbf{C}$ passes through the glucose pool.

$\$$ Assumes that 0.35 of urea-N is produced via protein catabolism but that all catabolized protein $\mathbf{C}$ passes through the glucose pool.

II Assumes that 0.35 of urea- $\mathrm{N}$ is produced via protein catabolism and that only 0.2 of catabolized protein $\mathrm{C}$ passes through the glucose pool, the rest being directly oxidized.

A minimum EPU can be calculated by assuming that all urea-N IRL could be attributed to protein- $\mathbf{N}$ catabolism. In this instance:

$$
\text { Minimum EPU }=\frac{x}{x+y} \text {. }
$$

Calculated values for 'corrected' EPU and minimum EPU are shown in Table 4.

Minimum EPU ranged from 0.32 to 0.58 . Corrected EPU ranged from 0.59 to 0.80 , with an over-all mean of 0.69 .

Measurement of EPU in this way does not require amino acid uptake from the small intestine to be measured, but the estimate is not independent of 'maintenance' needs for $N$. EPU is the net transfer of $\mathrm{N}$ passing through the 'free amino-acid- $\mathrm{N}$ ' pool and into milk protein. It would decline to zero in an animal at maintenance. EPU could be adjusted to be independent of 'maintenance' if urea production from protein- $\mathrm{N}$ catabolism at maintenance were known. At present it is not known for dairy cattle, but it is likely to be small compared with the rate of milk protein- $N$ secretion, so that these values for EPU can be used sensibly for describing protein allowances for high-yielding cows using systems such as that described by Roy et al. (1977).

There are few values with which to compare our estimates of corrected EPU. Oldham (1979) has calculated from other work on the oxidation of ${ }^{14} \mathrm{C}$ labelled amino acids by lactating cows that the equivalent efficiency factor for individual essential amino acids lies in the range $0.6 \mathrm{I}-0.84$. Oldham et al. (1979) have calculated EPU (equivalent to corrected EPU) to be $0.6-0.8$ (mean 0.69 ) by relating duodenal amino acid supply to rates of milk protein output and live-weight change in milking cows.

It is reassuring that these various estimates are similar. They should, however, be con- 
sidered only as range estimates. It remains to be shown what factors may be important in practice in causing EPU to vary.

\section{Gluconeogenesis from protein}

If it is assumed that urea production can be used to quantify the net rate of protein catabolism it is possible to consider to what extent $\mathbf{C}$ from catabolized protein may contribute to glucose IRL. This approach has previously been used by Nolan \& Leng (1970) working with pregnant sheep.

In the present experiments the maximum possible contribution of protein- $\mathrm{C}$ to glucose-C is found by assuming that all urea-N IRL is due to protein catabolism and that all catabolized protein-C is converted to glucose-C at the rate of $550 \mathrm{~g}$ glucose $/ \mathrm{kg}$ protein catabolized (Krebs, 1964).

Table 5 shows the proportions of measured glucose IRL which might be accounted for as glucose synthesized from amino acids if $(a)$ all urea IRL is due to protein breakdown and all catabolized protein is used for glucose synthesis; (b) 0.35 urea IRL is due to protein breakdown and all catabolized protein is used for glucose synthesis; and (c) $0.35 \times$ urea IRL is due to protein breakdown and only 0.2 of protein-C released on catabolism passes through the glucose pool, the rest being directly oxidized as suggested by Lindsay (1976).

Estimate $c$ is probably the most realistic estimate based on the previous comments regarding the source of urea and the observations, reviewed by Lindsey (1976) that the majority of amino acid-C catabolized is oxidized directly and does not pass through the glucose pool. On this basis it can be concluded that in the high-yielding dairy cow amino acids contribute no more than $2 \%$ of glucose IRL. A similar conclusion was reached by Oldham (I978), who used published values to calculate both glucose utilization rates and EPU in moderate- to high-yielding cows. Both estimates are much lower than some earlier estimates of the contribution of amino acids to gluconeogenesis in ruminants (Black et al. 1968; Nolan \& Leng, 1970; Reilly \& Ford, 1971), and probably reflect the particular metabolic demands of the high-yielding dairy cow.

I. B. acknowledges receipt of a grant from Marks \& Spencer Limited. We are grateful to Mr D. J. Napper and Miss D. Roberts for skilled technical assistance and Mr C. Bishop for help with the analysis of results.

\section{REFERENCES}

Agricultural Research Council (1965). Nutrient Requirements of Farm Livestock. No. 2, Ruminants. London. H.M. Stationery Office.

Allen, S. A. \& Miller, E. L. (1976). Br. J. Nutr. 36, 353.

Annison, E. F., Bickerstaffe, R. \& Linzell, J. L. (1974). J. agric. Sci., Camb. 82, 87.

Bennink, M. R., Mellenberger, R. W., Frobish, R. A. \& Bauman, D. E. (1972). J. Dairy Sci. 55, 712.

Bergman, E. N. \& Hogue, D. E. (1967). Am. J. Physiol. 213, 1378.

Bickerstaffe, R., Annison, E. F. \& Linzell, J. L. (1974). J. agric. Sci., Camb. 82, 71.

Black, A. L., Egan, A. R., Anand, R. S. \& Chapman, T. W. (1968). Isotope Studies on the Nitrogen Chain, p. 247. Vienna: International Atomic Energy Agency.

Bradbury, M. W. B. (1961). Br. J. Nutr. 15, 177.

Bradbury, M. W. B. \& Coxon, R. V. (1962). J. Physiol. Lond. 163, 423.

Brockman, R. P., Bergman, E. N., Pollak, W. L. \& Brondum, J. (1975). Can. J. Physiol. Pharmacol. 53, II86.

Bruckental, I., Oldham, J. D. \& Sutton, J. D. (1978), Proc. Nutr. Soc. 37, 107 A.

Cocimano, M. R. \& Leng, R. A. (1967). Br. J. Nutr. 21, 353.

Conrad, H. R. (1972). Tracer Studies on Non-Protein Nitrogen for Ruminants, p. 69. Vienna: International Atomic Energy Agency.

Ellenberger, H. B., Newlander, J. A. \& Jones, C. H. (1950). Vermont Agr. Exp. Sta. Bull. no. 558.

Engelhardt, W. v., Hinderer, S. \& Wipper, E. (1978). In Ruminant Digestion and Feed Evaluation, p. $4 \mathrm{I}$. [D. F. Osbourn, D. E. Beever \& D. J. Thomson, editors]. London: Agricultural Research Council. 
Evans, E., Buchanan-Smith, J. G., MacLeod, G. K. \& Stone, J. B. (1975). J. Dairy Sci. 58, 672.

Ford, A. L. \& Milligan, L. P. (1970). Can. J. Anim. Sci. 50, 29.

Horsfield, S., Infield, J. M. \& Annison, E. F. (1974). Proc. Nutr. Soc. 33, 9.

Hunter, G. D. \& Millson, G. C. (1964). Res. vet. Sci. 5, I.

Jones, G. B. (1965). Analyt. Biochem. 12, 249.

Judson, G. J. \& Leng, R. A. (1968). Proc. Aust. Soc. Anim. Prod. 7, 354.

Judson, G. J. \& Leng, R. A. (1972). Aust. J. biol. Sci. 25, 1313.

Kamal, T. H. \& Seif, S. M. (1969). J. Dairy Sci. 52, 1650.

Katz, J., Rostami, H. \& Dunn, A. (1974). Biochem. J. 142, 161.

Krebs, H. A. (1964). In Mammalian Protein Metabolism, vol, I, p. I 25. [H. N. Munroe \& J. B. Allison, editors]. New York: Acadernic Press.

Kronfeld, D. S. (1977). Fedn Proc. Fedn Am. Socs exp. Biol. 36, 259.

Kronfeld, D. S., Raggi, F. \& Ramberg, C. F. (1968). Am. J. Physiol. $215,218$.

Lindsay, D. B. (1976). In Protein Metabolism \& Nutrition, p. 186. [D. J. A. Cole, editor]. London: Butterworths.

Lindsay, D. B. (1979). Proc. Nutr. Soc. 38, 295.

McCance, R. A. \& Widdowson, E. M. (195I). Proc. R. Soc. B 138 , I 15.

Mahler, H. R. \& Cordes, E. H. (I97I). Biological Chemistry, 2nd ed. New York: Harper \& Row.

Marsh, W. H., Fingerhut, B. \& Miller, H. (1965). Clin. Chem. I1, 624.

Mugerwa, J. S. \& Conrad, H. R. (1971). J. Nutr. ror, 133 I.

Nolan, J. V. (1975). In Digestion and Metabolism in the Ruminant, p. 416 [I. W. McDonald \& A. C. I. Warner, editors]. Armidale: University of New England Publishing Unit.

Nolan, J. V. \& Leng, R. A. (1970). Br. J. Nutr. 24, 905.

Oldham, J. D. (1978). In Ruminant Digestion and Feed Evaluation, p. I3.I [D. F. Osbourn, D. E. Peever \& D. J. Thomson, editors]. London: Agricultural Research Council.

Oldham, J. D. (1979). In Protein Metabolism in the Ruminant. p. 5.I. [P. J. Buttery, editor]. London: Agricultural Research Council.

Oldham, J. D., Bruckental, I. \& Nissenbaum, A. (1980). J. agric. Sci., Camb. (In the Press.)

Oldham, J. D., Sutton, J. D. \& McAllan, A. B. (1979). Ann. Rech. Vet. 10, 290.

Ørskov, E. R. \& Grubb, D. A. (1979). Proc. Nutr. Soc. 38, 24 A.

Paterson, J. Y. F. \& Linzell, J, L. (1974). J. Endocr. 62, 371.

Reilly, P. E. B. \& Ford, E. J. H. (I971). Br. J. Nutr. 26, 249.

Roy, J. H. B., Balch, C. C., Miller, E. L., Drskov, E. R. \& Smith, R. H. (1977). In Protein Metabolism and Nutrition, p. I 26 [S. Tamminga, editor]. Wageningen: Pudoc.

Shipley, R. A. \& Clark, R. E. (1972). Tracer Methods for in vivo Kinetics. New York: Academic Press.

Snedecor, G. W. \& Cochran, W. G. (1967). Statistical Methods, 6th ed. Ames: The Iowa State University Press.

Somogyi, M. (1945). J. Biol. Chem. 160, 69.

Treacher, R. J., Little, W., Collis, K. A. \& Stark, A. J. (1976). J. Dairy Res. 43, 357.

Werner, W., Rey, H. G. \& Wielinger, H. (I970). Z. analyt. Chem. 252, 224. 